\title{
Misesian Ownership and Coasian Authority in Hayekian Settings: The Case of the Knowledge Economy
}

\author{
Foss, Nicolai J.
}

Document Version

Final published version

Publication date:

2001

License

CC BY-NC-ND

Citation for published version (APA):

Foss, N. J. (2001). Misesian Ownership and Coasian Authority in Hayekian Settings: The Case of the Knowledge Economy. The Link Program. LINK Working Paper No. 19

Link to publication in CBS Research Portal

\footnotetext{
General rights

Copyright and moral rights for the publications made accessible in the public portal are retained by the authors and/or other copyright owners and it is a condition of accessing publications that users recognise and abide by the legal requirements associated with these rights.

Take down policy

If you believe that this document breaches copyright please contact us (research.lib@cbs.dk) providing details, and we will remove access to the work immediately and investigate your claim.
}

Download date: 26. Apr. 2023 
(9667 words)

\title{
Misesian Ownership and Coasian Authority in Hayekian Settings: The Case of the Knowledge Economy
}

\author{
Nicolai J Foss \\ LINK \\ Department of Industrial Economics and Strategy \\ Copenhagen Business School \\ Howitzvej 60; 2000 Frederiksberg; Denmark \\ njf.ivs@cbs.dk
}

Revised draft, 2 July, 2001

\begin{abstract}
I critically discuss a number of recent and increasingly influential claims about economic organization in the "knowledge economy." The relevant claims are that traditional authority relations will tend to disappear, the boundaries of the firm will blur, and coordination mechanisms will be very malleable (resulting in various "new organizational forms"). In order to get an analytical focus on the knowledge economy, I assume that it may be approximated by "Hayekian settings" (after Hayek 1945), that is, settings in which knowledge is distributed and where knowledge inputs are relatively more important in production than physical capital inputs. I then argue, drawing on organizational economics as well as Mises' insights in property rights and comparative systems, that the presence of Hayekian settings does not mean that authority will disappear, etc. Thus, Misesian insights help to resurrect the Coasian firm against attacks inspired by Hayek's writings on knowledge.
\end{abstract}

\section{Acknowledgements}

The comments of Pat Gunning and two anonymous reviewers are gratefully acknowledged. 


\section{Introduction}

The present paper is taken up with the dynamics of economic organization. In particular, it critically discusses much recent work which has asserted that economic organization - in particular, the boundaries of firms, internal organization and corporate governance - will undergo major transformative changes as a result of the emergence of the so-called "knowledge economy," a term much fancied by business administration and management scholars (e.g., Prusak 1997; Neef 1998). An Austrian perspective is a particularly fitting starting point for such an exercise. Surely, Austrian economists - who have always been occupied with analyzing the discovery, dispersion and use of knowledge - will not be surprised to learn that we live in a knowledge economy. To Austrians, all economies are, in a broad sense, "knowledge economies." This calls for clarification of the concept. However, like its (somewhat overlapping, but non-identical) "new economy" counterpart in economics, the knowledge economy notion covers many different phenomena, ${ }^{1}$ and as in the case of the new economy, the evidence for these phenomena is somewhat scant, perhaps contrary to the impression provided by the considerable media (and some academic) hype. Recent research have established that some of changes usually packed into the notion, notably changes in the composition of the labor force (e.g., Tomlinson 1999) and some kinds of organizational changes (e.g., Ichniowski et al. 1996; Laursen and Foss 2002) appear to be very real ones, while evidence for other kinds of changes is perhaps less convincing.

However, the present paper is agnostic on the descriptive accuracy and significance of the full notion of the knowledge economy. The aim of the paper is to discuss, from an Austrian point view, economic organization in settings where rapid changes in the external environment necessitate a high degree of organizational decentralization and "empowerment" of employees, where relations to outside knowledge sources (other firms, universities, etc.) are paramount, and where "knowledge assets" account for a large (and increasing) part of value-added in production. While such settings have no doubt existed in some industries for a long time, they are not exactly the dominant mode of production that characterizes, say, American business history for a great part of the $20^{\text {th }}$ century (e.g., Chandler 1962; Langlois 2001). However, proponents of the knowledge economy notion assert that these settings are becoming increasingly prevalent in today's business landscape, in the sense that an increasing fraction of firms experiment with decentralizing their internal structures, build relations to external knowledge sources, etc. For the sake of argument, these parts of the knowledge economy

1 These include, on the organization side, a shrinking of corporate boundaries and new ways of structuring these, falling firm sizes, and a flattening of internal organization (e.g., Mendelsson and Pillai 1999; Helper, MacDuffie and Sabel 2000)); increased differentiation of tastes on the demand side (e.g., Milgrom and Roberts 1990); acceleration of innovation and technological development on the supply side (D'Aveni 1994); and changes in the composition of labor on the input side (Tomlinson 1999). 
notion shall be accepted in this paper. The question then is what drives such changes.

In order to understand this, many of those who have addressed economic organization in the knowledge economy have explicitly drawn upon Austrian more precisely, Hayekian - ideas on the need for decentralization fostered by the presence of dispersed knowledge. ${ }^{2}$ They have used such Austrian ideas to argue that hierarchy and planning methods are as problematic inside firms as they have proved to be outside firms, that firms need to harness the ability of markets to utilize, exchange and build information rapidly in response to changing contingencies, and that extensive delegation of decision rights and the use of highpowered incentives to support this are imperative. Fundamental changes with respect to IT innovations, internationalization, deregulation, increasing emphasis on shareholder value maximization, changes in the composition of the labor force, etc. have arguably made these Austrian principles of organizational design increasingly pressing. Perhaps not surprising, in many recent writings on all this, there is a strong and marked opposition to the central analytical dichotomy between planned firms and unplanned markets that is present not only in Coase (1937) and Williamson (1996), but also in central Austrian contributions such as Mises (1936, 1944, 1949) and Hayek (1973). ${ }^{3}$ Thus, it is argued that only those firms that emulate markets inside their internal organization to the largest possible extent will survive and prosper in the knowledge economy (Cowen and Parker 1997). The "Coasian firm," characterized by well-defined boundaries, authority, etc. will, in contrast, wither.

It is these ideas that the present paper critically takes issue with. In particular (but not exclusively), I focus on internal organization issues. Like a number of recent contributors, I discuss the implications for internal organization of the Hayekian notion that the dispersed and subjective character of relevant knowledge is a strongly binding constraint on the use of planned coordination. However, I argue that it does not follow that firms should emulate markets as far as possible. In his critique of market socialism, Mises (1949) pointed to the folly of "playing markets," and I draw on his overall argument that bringing coordination mechanisms characteristic of market organization into a planned organization is inherently problematic. I also draw on Mises' (1949) related insight that the mixed economy is fundamentally unstable, as well as on his insights in property rights and ownership (Mises 1936, 1949; Foss 1994a). Mises argued that the economic institutions of capitalism are strongly complementary in the sense that (unhampered) capitalism is a stable system, consisting of interlocking elements, where changes away from pure capitalism will result in serious inefficiencies. I use this fundamental notion to argue that firms are also systems of complementary

2 Examples include Ellig (1993, 1997), Ellig and Gable (1993), Cowen and Parker (1997), Foss (1999, 2000), Ghoshal, Moran and Almeida-Costa (1995), Grant (1996), Jensen and Meckling (1992), Jensen and Wruck (1994), Hodgson (1998), and Nonaka and Takeuchi (1995).

3 Cowen and Parker (1997) and Matthews (1998) are particularly outspoken critics of the dichotomy. 
elements and that this fact places constraints on the extent to which firms may be made "market-like." In particular, I agree with Mises that "[t]he function of the entrepreneur cannot be separated from the direction of the employment of factors of production for the accomplishment of definite tasks. The entrepreneur controls the factors of production" (Mises 1949: 306). The "direction" and "control" undertaken by "the entrepreneur" is qualitatively different from allocation by means of the price mechanism, since it relies on authority that is backed up by the entrepreneur's ownership of the alienable (non-human) means of production. In other words, Misesian arguments are used to criticize arguments derived from Hayekian insights that firms should emulate markets to the largest possible extent. In a sense, Misesian arguments resurrect the Austrian and Coasian notion that markets and hierarchies are indeed different mechanisms for resource allocation; hence, the title of the paper. ${ }^{4}$

\section{Economic Organization in the Knowledge Economy: Interpreting Recent Arguments}

\section{Economic Organization in the Knowledge Economy: Some Recent Arguments}

To repeat, the notion of the knowledge economy is used (and accepted) here to cover ongoing changes in the business landscape, such as the increase in the relative numbers of firms experimenting with decentralizing their internal structures (Ichniowski et al. 1996) and building relations to external knowledge sources (Liebeskind et al. 1995; Matusik and Hill 1998), the tendency of knowledge assets to account for an increasing share of value-added and physical assets for a decreasing share, and the changing skill composition of the workforce (Tomlinson 1999). Numerous writers have argued that tasks and activities in the knowledge economy need to be coordinated in a manner that is very different from the management of traditional manufacturing activities (as portrayed in, e.g., Chandler 1962). This has profound transforming implications for the authority relation and the internal organization and boundaries of firms. For example, Cowen and Parker (1997) explain with respect to internal organization that

Market changes are moving manufacturing farther and farther away from steady-state, low variety, long-batch production runs, relevant to Taylorist methods, to high variety and small runs ... Organizations are adopting new forms of decentralization to cope with the instability, uncertainty, and pace of change of the market-place ... In cluster of network working, employees of undifferentiated rank may operate temporarily on a certain

$4 \quad$ Foss (1994b) argued that in many important respects, the Austrians anticipated ideas that have become prominent in the modern economics of organization. The arguments developed in the present paper go beyond those in Foss (1994b) by putting more stress on Misesian arguments. Foss (1993) argued that Coasian insights were largely consistent with an Austrian perspective, contrary to Boudreaux and Holcombe (1989). Klein (1996) is an application of the Misesian calculation argument to the issue of the boundaries of the firm, and Klein and Klein (2001) treat corporate governance issues in a Misesian manner. 
task or tasks in teams. The clusters are largely autonomous and engage in decentralized decision-making and planning ... They are conducive to individual initiative ('intrapreneurship') and faster decision-taking. They facilitate organizational flexibility.

A number of writers also argue that firm boundaries will be profoundly affected by the emerging knowledge economy. Specifically, because of the growing importance of being able to access knowledge from multiple sources, knowledge-based networks (Harryson 2000) increasingly become the relevant dimension for understanding the organization of economic activities. Such networks often cut across the legal boundaries of the firm. ${ }^{5}$

This increased reliance on knowledge networks tends to erode authority-based definitions of the boundaries of the firm, because authority increasingly shifts to expert individuals who control crucial information resources and may not be employees of the firm. As Zucker (1991: 164) argues:

While bureaucratic authority is by definition located within the firm's boundaries, expert authority depends on the information resources available to an individual, and not on the authority of office. Thus, authority may be located within the organization ... but when an external authority market can provide information that leads to greater effectiveness, then authority tends to migrate into the market.

To the extent that important knowledge assets are increasingly controlled by employees ("knowledge workers") themselves, traditional authority relations are fading into insignificance. This is partly a result of the increased bargaining power on the part of knowledge workers (stemming from the control over critical knowledge assets), and partly a result of the increasingly specialist nature of knowledge work (Hodgson 1998), which makes principals/employers ignorant about (some of) the actions that are open to agents/employees.

The combined effect of all this is to wreck the traditional economist's criterion of what distinguishes market transactions from hierarchical transactions (Zingales 2000). Thus, whether direction by means of order giving (Coase 1937; Simon 1951; Williamson 1985; Demsetz 1991) and backed up by the ownership of alienable assets (Hart and Moore 1990) obtains or not is increasingly irrelevant for understanding the organization of economic activities in a knowledge economy (cf. Grandori 2001). It is therefore not surprising that a number of writers are quite explicit that the advent of the knowledge economy increasingly questions the relevance of Coasian organizational economics (e.g., Boisot 1998; Helper, MacDuffie and Sabel 2000). Thus, Cowen and Parker (1997: 15; emphasis in original) argue that

5 The underlying comparative-institutional argument is that networks are particularly useful organizational arrangements for sourcing and transferring knowledge because the costs of pricing knowledge (in a market) or transferring it (in a hierarchy) often exceed the costs of transmitting knowledge within an informal network (Powell 1990: 304; Liebeskind et al. 1995: 7). 
... firms and markets are not exactly the same, but rather they differ in empirical terms. They refer to different means of organizing economic activity, albeit means that do not differ substantially in kind. ... This ... view does not seek to find a clear-cut distinction between firms and markets. Rather the difference between the firm and the market as a resource allocator involves what might more usefully be viewed as subtle differences relating to contracting. ${ }^{6}$

It is easy to see that the above arguments go right to the heart of the crucial and perennial issues in the theory of economic organization. However, before it is possible to provide a response, it is necessary to understand on what basis one may put forward such arguments. Austrian economics is a particularly fitting starting point for such an exercise.

\section{Economic Organization in Hayekian Settings}

It is no coincidence that so many of those who write on economic organization in the emerging knowledge economy cite Hayek's work, particularly his 1945 paper, "The Use of Knowledge in Society"; indeed, much of what these writers are up to may be understood as an attempt to examine the implications of that particular paper for the theory of the firm (cf. Ghoshal, Moran and Almeida 1995; Nonaka and Takeuchi 1995). In particular, writers inspired by Austrian economics have analyzed the implications of the knowledge economy for firm organization in terms of the planning problems posed by Hayekian dispersed knowledge becoming increasingly pressing for firms (Cowen and Parker 1997). Coping with the problem posed by Hayekian distributed knowledge has moved from being a problem for socialist managers and dirigiste bureaucrats to also being a problem confronted by managers of (at least large) firms in capitalist economies.

Two key claims (or, "stylized facts") - which may both be characterized as Hayekian in spirit - are present in recent work on economic organization in the knowledge economy. The first claim is that because of the increased need for firms to source diverse, specialized knowledge in production, knowledge, as seen from the point of view of a manager, is becoming increasingly dispersed in the sense of Hayek (1945). In other words, why such knowledge is not possessed by any single mind, it is still necessary to somehow mobilize it for the carrying out of a productive task or a complex of such tasks. ${ }^{7}$ The second claim is that because of the increased importance of sourcing specialist knowledge, knowledge assets controlled by individual agents ("knowledge workers") are becoming increasingly important in production (e.g., Boisot 1998; Hodgson 1998) in the sense of accounting for a greater part of the value-added of goods. In the following, I refer to situations in which these two claims are descriptively adequate as "Hayekian settings."

6 This quotation echoes earlier statements by Alchian and Demsetz (1972) and Cheung (1983), reinforced by Hayekian considerations.

7 This argument is made explicitly by, for example, Ghoshal, Moran and Almeida-Costa (1995), Hodgson (1998), and Coombs and Metcalfe (2000), 
One possible interpretation of the recent literature on economic organization in the knowledge economy is that as Hayekian settings become increasingly prevalent, traditional authority relations vanish (Zucker 1991; Hodgson 1998); the boundaries of firms blur because of the increasing importance of knowledge networks that transcend those boundaries; and coordination mechanisms (i.e., authority, norms, teams, prices, etc.) will increasingly be combined in new, innovative ways - resulting in what is often referred as "new organizational forms," and substituting for traditional relations of authority. This final claim implies that organizational forms do not cluster in a few rigid, discrete forms, but, on the contrary, that coordination mechanisms are highly malleable (e.g., Grandori 1997; Helper, MacDuffie and Sabel 2000). In particular, firms may adopt coordination mechanisms that we normally think of as characteristic of the market rather than of planned coordination, in particular pricing, entrepreneurial control over resources, and high-powered incentives (Miles et al. 1997). In the following, I interpret and discuss some of these arguments. It is convenient to begin with a discussion of the meaning of authority.

\section{The Hayekian Challenge to Economic Organization}

To most economists, Coase's (1937) discussion, supplemented with a later contribution by Simon (1951), still provides the working definition of authority. In Coase (1937: 242), the employment contract is explained as

... one whereby the factor, for a certain remuneration (which may be fixed or fluctuating) agrees to obey the directions of an entrepreneur within certain limits. The essence of the power is that it should only state the limits to the powers of the entrepreneur. Within these limits, he can therefore direct the other factors of production.

This contractually agreed upon right to "direct the other factors of production" is, of course, authority. Much debate in economics has concerned the sources of authority (e.g., Alchian and Demsetz 1972; Cheung 1983; Hart 1995). In other words, why exactly is it that the employee accepts to be directed when human capital cannot be traded? ${ }^{8}$ However, in Hayekian settings, other questions - which have been much less discussed - are just as pertinent. Thus, if in Hayekian settings, the employer does not possess full knowledge of the employee's action set (i.e., the actions that he can take when uncertainty is resolved), or if the employee is better informed than the employer with respect to how certain tasks should (optimally) be carried out, or if employees control knowledge assets that are "within their heads" and which may give them substantial bargaining power, what happens to the Coasian notion of authority as direction? It is easy to conclude that under these circumstances,

8 Thus, to writers such as Alchian and Demsetz (1972) and Cheung (1983), it is not meaningful to assume that an employer can force an employee to do what the employer wants in the absence of coercion. As Alchian and Demsetz (1972) argue, an implication of this view is that the distinction between the authority-based and the price-based modes of allocation emphasized by Coase (1937) is superficial. Note that this "nexus of contracts" position is remarkably close to the position that in a knowledge-based economy, the firm/market boundary is unclear and the notion of authority elusive at best. 
Coasian authority simply is not a workable mechanism for allocating resources (and some writers appear to have explicitly adopted this position, e.g., Grandori 1997), for the basic reason that this notion seems to assume that a directing employer is at least as knowledgeable about the relevant tasks as the employee being directed.

It has recently been argued, in response to Alchian and Demsetz (1972), that ultimately the source of authority is ownership of assets (Hart 1995). If an employer has the power to deprive a worker of access to assets (to which he may have become specialized), the employer obtains bargaining power that forms the backbone of the authority he can exercise over the employee. At the same time, this provides a theory of the boundaries of the firm, since these may be defined in terms of ownership of assets. The assets that in this line of thought confer authority are alienable assets. However, as numerous writers have emphasized, an important aspect of the knowledge economy is precisely that physical assets are of strongly waning importance (e.g., Boisot 1998). Of course, the implication is that ownership over such assets is an increasingly ineffective source of bargaining power and that, therefore, authority must wane as bargaining power increasingly becomes more symmetrically distributed over the owners of knowledge assets. Since the boundaries of the firm are (also) defined in terms of legally recognized ownership to the firm's alienable, primarily physical, assets, and since such assets are of declining economic and commercial importance, it is obvious that the very notion of the firm's boundaries is becoming increasingly fuzzy, and perhaps even irrelevant.

Finally, because authority declines in importance as knowledge becomes distributed and knowledge inputs increase in importance, resort to other coordination mechanisms is necessary. Thus, firms increasingly rely on highpowered incentives, implement employee stock-ownership programs, invest in building "corporate cultures," try to price corporate resources to the largest possible extent, etc. An outcome of this is the emergence of "new organizational forms." The theoretical implication is that various mechanisms for coordinating resources are combine to a much larger extent than hitherto assumed in, for example, organizational economics, where economic activities are normally assumed to be organized across three discrete governance structures, firms, markets, and hybrids (e.g., Williamson 1996).

In sum, arguments can be made that Hayekian settings, where knowledge is distributed and knowledge inputs are more important than physical capital inputs, present real problems for the exercise of authority in firms, make the boundaries of firms blur, and remove many of the constraints on the malleability of coordination mechanisms. The following section discusses the reach of these arguments.

\section{Authority, Firm Boundaries and Complementary Coordination Mechanisms in Hayekian Settings}

In this section, I assume that Hayekian settings obtain and discuss the implications of such settings for the Coasian themes of authority, the boundaries of the firm, and the combinability of coordination mechanisms. The underlying perspective is 
Misesian, in the sense that I shall throughout assume the existence of a speculating entrepreneur. The entrepreneur is ultimately in charge of the business venture in the sense that he determines "... the general plan for the utilization of resources" (Mises 1949: 303), hires the managers and "technicians, i.e., people who have the ability and skill to perform definite kinds and quantities of work" (idem.), determines "... the expansion and contraction of the size of the business and its main sections," as well as "the enterprise's financial structure" (1949: 307), and acquires ownership of the firm's alienable assets. Nobody denies that in the emerging knowledge economy, there will still be a need for such enterprising agents. On the contrary, many recent writings on the knowledge economy very strongly stress entrepreneurship (e.g., Miles et al. 1997). What is being claimed is rather, as we have seen, that the entrepreneur will no longer be able to exercise much authority, that the boundaries of his venture will become ill-defined (if not in a formal, legal sense, then in an economic and commercial), and that his venture can rely on all sorts of combinations of coordination mechanisms, in particular that he can offer employees incentives that in terms of their strength (i.e., the way in which they link effort and rewards/punishment) are very close to the incentives provided under market contracting, effectively mimicking the effects of market pricing. I discuss the three issues of authority, boundaries and malleability of coordination mechanisms seriatim.

\section{Authority in Hayekian Settings}

In this section, the strategy is to examine the role of authority in Hayekian settings. Since I later discuss the importance for economic organization of the distinction between physical and knowledge assets, I here only concentrate on the dispersed knowledge aspect of Hayekian settings. One way of doing this is to focus on "hidden knowledge" (Minkler 1993) in relations between a principal (e.g., the Misesian entrepreneur) and an agent (e.g., a hired manager). That is, it will be assumed that the problem facing a principal is not just that he is uninformed about what state of nature has been revealed or of the realization of the agent's effort (i.e., hidden information), as in the usual agency model (Holmström 1979), but that the agent's knowledge is superior to that of the principal with respect to certain production possibilities (i.e., hidden knowledge). The principal may be ignorant about some members of the set of possible actions open to the agent, or the agent may be better informed than the employer with respect to how certain tasks should (optimally) be carried out, or both. As I shall argue, it is possible to explain the presence of authority in such a setting, in the sense of it being rational to give one agent decision-making power over another one. I discuss the rationales for this under the headings of "the need for urgent coordination," "decisive information," "economies of scale in decision-making,", and "defining incentive systems."

The Need for Urgent Coordination. While Hayek (1945) did much to identify the benefits of the price system in the context of alienable property rights in coping with distributed knowledge and unexpected disturbances, he arguably neglected those situations where efficiency requires that adaptation be "coordinated" rather than "autonomous" (Williamson 1996). Coordinated adaptation or action may be 
required when actions or activities are complementary (Milgrom and Roberts 1990; Kirsten Foss 2001), for example, when it is important to make some urgent choice (possibly highly inefficient), because doing nothing is worse. In such cases, it may be better to have somebody pick a strategy and make everybody play this strategy, if the inefficiencies from picking a bad strategy are smaller than the inefficiencies from delaying a coordinated solution. In the context of a specific model of this trade-off, Bolton and Farrell conclude that “... the less important the private information that the planner lacks and the more essential coordination is, the more attractive the central planning solution is" (1990: 805). Moreover, the decentralized solution performs poorly if urgency is important. Centralization is assumed to not involve delay and therefore is a good mechanism for dealing with emergencies, a conclusion Bolton and Farrell argue is consistent with the observed tendencies of firms to rely on centralized authority in cases of emergencies.

Decisive Information. Even under distributed knowledge, where the centralized decision-maker per definition does not possess (at least some) local information, he may in many cases still hold the information that is decisive. Loosely, information is (strongly) decisive if — in a setting involving many cooperating individuals - a decision can reasonably be made on the basis of this information without involving other pieces of information (Casson 1994). According to Casson (1994), the extent to which a problem involving the knowledge of several individuals has decisiveness features and the cost at which knowledge can be communicated helps to explain the allocation of decision rights. The general principle is that decision rights will tend to be concentrated in the hands of the individual who has access to the decisive information, and particularly so the more costly it is to communicate this information. This provides a further argument for authority under hidden knowledge. If the knowledge possessed by, for example, managers is not decisive, if the knowledge possessed by the entrepreneur is decisive, and if it is costly to communicate the entrepreneur's knowledge, then overall decision rights should be concentrated in the hands of the entrepreneur, that is, he should assume ultimate authority in the firm.

Economies of Scale in Decision-Making. Demsetz (1988) argues that economies of scale in managing are a neglected factor in the explanation of the existence of firms and the understanding of authority. However, he does not explain the underlying reasoning. However, the relevant economies may relate both to managing the internal relations between agents inside the firm and managing relations to outside agents (customers, suppliers, government agencies. Not only may there be scale economies in such activities; there may also be substantial learning economies. Other agents may be happy to let a central agent incur the effort costs of negotiating, learning about potential suppliers, etc., and compensate him accordingly.

Defining Incentive Systems. It is hard to deny to that Hayekian settings pose special problems for the use of monitoring mechanisms and incentive pay (Minkler 1993; Aghion and Tirole 1997; Foss 1999). Minkler (1993: 23) argues that “... if the worker knows more than the entrepreneur, it is pointless for the entrepreneur to monitor the worker," which implies that to the extent that monitoring is a 
precondition for the exercise of direction, using the authority mechanism also seems to become "pointless." However, even under hidden knowledge, there may still be a role for authority. For example, even under hidden knowledge the principal may be able to form conjectures of the financial results that result from the agent's activities and he can check whether these conjectures are actually confirmed using the control systems of the firm. Both Knight (1921), discussing business judgment and Mises (1949: 303), discussing the entrepreneur delegating responsibilities to managers, clearly allowed for this possibility. None of them assumed that entrepreneurs would have full knowledge of their managers' action set; still, they did assume that the entrepreneur can rationally delegate decisions to managers and control these. Hidden knowledge does not imply that subjective performance measurement becomes impossible. In fact, it may be conjectured that the more we depart from simple settings where employees are very easily monitored, and the more complicated the control problem becomes, the more likely is it that the entrepreneur will choose to rely on multiple incentive instruments to influence employee behavior (Holmström and Milgrom 1991). In a dynamic economy, maintaining coherence between such instruments may be a recurrent task. Economies of scale may dictate that this activity be centralized. Moreover, centralization is required to the extent that externalities arise when the instruments are controlled by separate firms and transaction costs hinder the internalization of these externalities. Both arguments point towards the centralization of decision rights

Thus, the above arguments suggest that it is in fact possible to explain authority in the sense of possessing rights to somehow direct another agent in the context of Hayekian settings. Admittedly, authority understood narrowly as a relation in which the employer has superior knowledge and can observe all contingencies that require a response by an employee is not consistent with such settings. But firm organization does not at all necessitate this kind of authority relation. The very fact that firms exist is prima facie evidence that they can somehow cope with the problems implied by Hayekian settings. ${ }^{9}$ In turn, this suggests economists are well-advised to scrap the narrow understanding of authority with which they have typically worked.

\section{Delegation as a Response to Hayekian Settings}

The reason that firms can thrive even though their internal organization exemplify Hayekian settings is that they have recourse to delegation. ${ }^{10}$ As Mises (1949: 303) emphasized, “... entrepreneurs are not omnipresent. They cannot themselves attend to the manifold tasks which are incumbent upon them." Mises (1949: 305) clearly recognized that in many firms decision rights are allocated by the

9 Of course, there are also offsetting benefits of firm organization, such as the superior ability of firms to organize transactions characterized by high-levels of relation-specific investments (Williamson 1985, 1996; Grossman and Hart 1986; Hart and Moore 1990).

10 An alternative mechanism is to suppress Hayekian settings as possible by discouraging local initiative, indoctrinating employees harshly, and operating with rigid routines and operating procedures. In a dynamic economy, this is, however, bound to lead to financial disaster. 
entrepreneur (and the board of directors) to lower levels, presumably in order to better cope with distributed knowledge, an insight that is not present in Coase (1937). He perceptively recognized that delegation leads to agency problems, but argued that the system of double-entry bookkeeping and other control measures may partly cope with such problems. Mises also understood that delegation of decision rights is circumscribed in an attempt to cope with the control problem that follows from delegation. ${ }^{11}$

In the Misesian scheme, an organizational equilibrium obtains where decision rights are delegated in such a way that the benefits of delegation in terms of better utilizing local knowledge are balanced against the costs of delegation in terms of agency losses (as in Jensen and Meckling 1992). This provides a useful perspective on many of those new organizational forms that are argued to be characteristic of the knowledge economy (cf. Cowen and Parker 1997), such as team-organization, "molecular forms", and other manifestations of organizational delegation and decentralization: These are prompted by a market-driven pressure to delegate decision rights (e.g., to better serve customer preferences) and structure reward schemes in such a way that optimal tradeoffs are reached. Thus, decision rights are delegated inside firms, but they are delegated as means to an end (Hayek 1973), their use is monitored (Jensen and Meckling 1992), and top-management reserves ultimate decision rights for itself (Baker, Gibbons, and Murphy 2000).

This underscores the argument made earlier that authority in the sense of direction and centralized decision-making — which, as Mises emphasized, does not require detailed knowledge about a subordinate's knowledge or available actions may persist in Hayekian settings. Per implication, even in "knowledge-based" firms, there may be a need for centralized coordination. As I shall argue next, when there is such a need, it is often efficient to centralize ownership to alienable assets. In turn, this suggests that centralized coordination is a feature of firms rather than markets.

\section{Ownership and the Boundaries of Firms}

So far, not much has been said about what backs up authority, although it has been hinted at that ownership may play a key role here. The purpose of the present section is to go more into ownership issues, and therefore the issue of the boundaries of the firm. The argument that will be critically discussed is that as knowledge assets become relatively more important in production, the boundaries of firms will blur, at least to the extent that these are defined in terms of legally recognized ownership of the firm's alienable assets. The work of Oliver Hart and others (Hart 1995, 1996; Hart and Moore 1990) - called the incomplete-contracts literature - offers a possible approach to this issue. The incomplete contracts approach is a thoroughly neoclassical approach, not an Austrian one. However, it has some features that makes complementary to a Misesian perspective, notably the

11 For example, the right to use an asset in certain ways may be delegated; however, it is understood that that right does not entail the right to, for example, use the asset in the service of a competitor firm. 
emphasis on ownership as backing up authority, the argument that the boundaries of the firm lies where the entrepreneur's ownership of alienable assets stops, and the implication that the entrepreneur assumes his directing role because his inputs to the venture are those that matter the most for the total monetary surplus.

In the Hart approach, two kinds of assets are distinguished, namely alienable (i.e., non-human) and non-alienable (i.e., human) assets. The basic distinction between an independent contractor and an employee, that is, between an inter-firm and an intra-firm transaction, now turns on who owns the alienable assets that an agent (whether independent or employee) utilizes in his work. An independent contractor owns his tools etc., while an employee does not. The importance of asset ownership derives from the fact that the willingness of an agent to undertake a noncontractible investment (say, exertion of effort or investment in human capital), which is specific to the asset, depends on who owns the asset. The parties to a relation are seen as being in a bargaining situation, each having an outside option. Given this, the division of the surplus from the relation will depend on who owns the alienable assets in the relation, since the pattern of ownership will influence the parties' outside options..$^{12}$ In turn, the expectation of this division feeds back into the investments that the parties are willing to make. Efficiency considerations then suggest that authority (i.e., ownership to the alienable assets) should be allocated to the agent who makes the most important (non-contractible) relation-specific investment.

This kind of reasoning may be utilized to get an understanding of the implications of knowledge assets for the boundaries of the firm. Assume, therefore, a purely "knowledge-based" team, consisting of two agents and two knowledge assets. In this team, the entrepreneur owns a knowledge asset that is "inside his head" (e.g., an entrepreneurial idea) and the other agent, the scientist, owns the only other asset in the relation which we may assume to be a patent. Both assets are necessary to the create value in the relation, and they are (strictly) complementary, so that any asset is of zero value without the other. It is prohibitively costly to communicate the knowledge embodied in the entrepreneurial idea from the entrepreneur to the scientist, so it is effectively non-alienable. Moreover, it is not possible to write a comprehensive contract, governing the use of the assets in all contingencies. Given this, we may ask who should own the (alienable) patent which - in terms of incomplete contracts approach - is the same as asking who should own the firm.

In this setting, if the entrepreneur makes an effort investment, that is, elaborates on his idea and creates extra value, the scientist can effect a hold-up on the entrepreneur, since the latter needs access to the patent to create value (and the contract is incomplete). Of course, the reverse also holds, so that if the scientist makes an effort investment, for example, makes a spin-off patent, the entrepreneur

12 For example, if the employer owns all the alienable assets, the employee can still quit if he dislikes the employer's orders (as in Alchian and Demsetz 1972), but he cannot take the assets with him, and the employer can ensure that if the employee leaves, somebody else can take over the job. 
can hold-up the scientist by threatening to withdraw from the relation. One can show (details in Hart and Moore 1990 and Brynjolfsson 1994) that because of the externality problem that the hold-up threat creates, every agent invests too little; specifically, each party invests to the point where the marginal cost of effort investment equals $1 / 2$ of the marginal value (because they are assumed to split the extra surplus $50: 50$ ). Suppose now that the entrepreneur owns both the patent and the entrepreneurial idea. This will strengthen the entrepreneur's incentives (the scientist cannot hold him up anymore) and it will leave the scientist's incentives unaffected. Rational agents will choose this arrangement.

The conclusion is that it is possible to speak of the boundaries of the firm in terms of ownership - even in a situation where all relevant productive assets are knowledge assets. However, this does not yet demonstrate the point made earlier, namely that authority and ownership somehow go together. This issue can be addressed, however, by assuming that one of the agents, the entrepreneur, have decisive information (in the sense discussed earlier). While it argued earlier that it would be rational to give this agent decision rights amounting to authority, should he also be an owner? Consider a bigger "knowledge-based" firm where there is a group of $n$ scientists $(n>1)$ who each owns a patent. The entrepreneur, who again comes equipped with a non-alienable entrepreneurial idea, aggregates information from the messages of the scientists and directs their efforts. His knowledge is decisive in the sense that without it, all actions of the other agents produce zero value. The entrepreneur may improve on this decisive knowledge. Each agent needs access to his own patent and to the entrepreneur's direction in order to be productive. Given these assumptions, the hold-up problem is still present: Any one of the scientists can hold up the entrepreneur on his investment, leading the entrepreneur to choose inefficient investment levels. However, if the entrepreneur is given ownership to the alienable assets, that is, the patents, the hold-up problem disappears. Rational agents will choose this arrangement.

\section{Are Coordination Mechanisms Malleable?A Misesian Perspective}

Thus far, it has been argued that it is possible to provide rational reasons for authority, for ownership-based notions of the boundaries of the firm, and for authority and ownership being linked, even in Hayekian settings. This prompts the question of whether there are other necessary "links" between organizational elements. Here it is pertinent to turn once more to Mises' work, in particular Mises' work on political economy and comparative systems.

As Mises (1949: 709) explained, there are inherent contradictions involved in "playing market," which we may broadly interpret as the introduction of pricing in the context of hierarchy. With reference to various socialist schemes of his day that tried to preserve some market relations while eliminating capital and financial markets, Mises argued that these schemes would be unworkable. To an important extent this is a matter of the sheer impossibility of rational calculation when asset markets are eliminated. But Mises also placed much emphasis on property rights and ownership issues (particularly Mises 1936). Thus, he was aware that the concentration of ultimate decision-making rights — that is, ownership — in the 
hands of a central planning board would dilute the incentives of socialist managers. While planning authorities could (and according to the more "sophisticated" schemes of the day, should) delegate rights to make production and investment decisions to managers, these rights could not be used in a rational manner. First, since managers could not be sure that they would not be overruled by the planning authorities, they were not likely to take a long view, notably in their investment decisions. Moreover, since managers were not the ultimate owners, they were not the full residual claimants of their decisions and, hence, would not make efficient decisions. Thus, in addition to his pure calculation argument, Mises also put forward property rights arguments for why the attempt to "play market" under socialism would not be workable.

Firms have the great advantage relative to socialist planning boards that they may to a much larger extent rely on the prices of outside markets. Thus, the Misesian calculation problem, while helping to explain the sizes of firms (Klein 1996), does not imply that firm organization is "impossible." However, some of the property rights insights into socialism also apply to firms. In particular, a good deal of recent analytical energies have been devoted to the commitment problems of delegation in firms (e.g., Williamson 1985; Miller 1992; Baker, Gibbons, and Murphy 1999). Transaction cost economist, Oliver Williamson (1996) has referred to these kinds of problems with his concept of the "impossibility of (efficient) selective intervention." The main problem is that incentives are diluted. This is because the option to intervene "... can be exercised both for good cause (to support expected net gains) and for bad (to support the subgoals of the intervenor)" (Williamson 1996: 150-151). Promises to only intervene for good cause can never be credible, Williamson argues, because they are not enforceable. Although Williamson may be going to far, a main conclusion in this literature is indeed that credible delegation may be very hard to accomplish, since reneging on a promise to delegate will in many cases be very tempting and those to whom rights are delegated anticipate this. ${ }^{13}$ An immediate implication of this kind of reasoning is that emulating market

13 In a recent treatment, the problem is stated in the following way (cf. Baker, Gibbons and Murphy 1999). Assume that a subordinate initiates a project, where a "project" may refer to many different types of decisions or clusters of decisions. Assume further that the manager has information that is necessary to perform an assessment of the project, but that he decides upfront to ratify any project that the subordinate proposes. Effectively, this amounts to full informal delegation of the rights to initiate and ratify projects — "informal," because the formal right to ratify is still in the hands of the manager and because that right cannot be allocated to the subordinate through a court-enforceable contract (cf. Williamson 1996). Because the subordinate values being given freedom, this will induce more effort in searching for new projects (Aghion and Tirole 1997). The expected benefits of these increased efforts may overwhelm the expected costs from bad projects that the manager has to ratify. However, the problem is that because the manager has information about the state of a project ("bad" or "good"), he may be tempted to renege on a promise to delegate decision authority, that is, intervene in a "selective" manner. But if he overrules the subordinate, the latter will lose trust in him, holding back on effort. Clearly, in this game a number of equilibria are feasible. The particular equilibrium that emerges will be determined by the discount rate of the manager, the specific trigger strategy followed by the sub-ordinate (e.g., will he lose trust in the manager for all future periods if he is overruled?), and how much the manager values his reputation for not 
organization inside firms, for example, by radically decentralizing the firm and allocating far-reaching decision rights to employees may be hard to accomplish in a successful manner. Unlike independent agents in markets, corporate employees never possess ultimate decision rights. They are not full owners. This means that those who possess ultimate decision rights can always overrule employees. Thus, there are incentive limits to the extent to which market mechanims can be applied inside firms, and delegation, while not exactly a rare flower, is certainly a very delicate one.

Other means of introducing market mechanisms inside firms are also problematic, if for somewhat different reasons. Thus, multi-task agency theory suggests that there are quite rational reasons for the "low-powered" incentives one typically observes inside firms (in contrast to the "high-powered" incentives of the marketplace) (Holmström and Milgrom 1991). This is because managers wish employees to undertake multiple tasks, some of which may be very costly to observe and measure, but which may nevertheless be vital to the firm (e.g., sharing knowledge with colleagues, handling calling customers in a polite manner, etc.). Providing incentives that are only tied to those tasks that can be measured (at low cost) risks twisting efforts away from the costly-to-measure tasks. These problems would appear to be particularly acute in Hayekian settings, because of dispersed knowledge.

Taken together the reasoning above suggests that coordination mechanisms are not simply combinable in an arbitrary fashion, contrary to the thrust of many recent writings on economic organization in the knowledge economy. Ultimately, this is because authority and ownership will continue to be important in the knowledge economy, as argued earlier. First, it has been argued that there is an inherent tension between ownership and delegated rights. Second, in Hayekian settings, delegation is necessary. Delegation often needs to be backed up by a strengthening of incentives because of the agency problem. However, under multitasking, there are limits to how much incentives can be strengthened. Thus, rather than being combinable at will, coordination mechanisms, such as authority, delegation, pricing, etc., tend to cluster in predictable ways. This is an application of sorts on the level of the firm of Mises' demonstration that the various elements that make up the capitalist market economy are complementary ones; one cannot simply take a subset of these away, say, unhampered capital markets, and substitute them with elements that are characteristic of a different system. ${ }^{14}$ In a similar manner, concentrated ownership, authority, circumscribed decision rights, and incentives that are less "powered" than those of the marketplace are all complementary elements of a system, namely, the firm, and they will continue to be so, even in the knowledge economy. Thus, Misesian arguments help to demonstrate the continued viability of the "Coasian firm," as against those critics who have

reneging relative to the benefits of reneging on a bad project (for details and extensions, see Baker, Gibbons, and Murphy 1999).

14 See also Milgrom and Roberts (1990) for an important discussion of complementarities. 
argued that it will wither under the impact of the increasing prevalence of Hayekian settings.

\section{Conclusion}

The understanding of the dynamics of economic organization, such as what will happen to authority relations, the boundaries of firms and firms' use of distinct coordination mechanisms, is a task of almost forbidding complexity. Yet, a combination of organizational economics and Austrian insights, primarily represented by the works of Hayek and Mises, provides useful insights. The approach of this paper has been to try to distill some key assumptions and propositions that characterize much of this literature, and examine these in the light of organizational economics and Austrian economics.

Thus, it has been argued that much of the recent discussion of economic organization in the knowledge economy may be distilled into a basic assertion that the kind of knowledge that Hayek (1945) talked about represent an increasingly binding constraint on the exercise of authority, makes the boundaries of firms blur, and necessitates the use of multiple coordination instruments to efficiently utilize this knowledge. To the extent that increasingly firm hierarchies do flatten, functions are spun-off in an attempt to improve incentives, delegation increases, etc., much of this may be interpreted using insights originally put forward by Hayek, as a number of writers have pointed out already (Ellig 1993; Gable and Ellig 1993; Ghoshal, Moran and Almeida-Costa 1997; Cowen and Parker 1997; Foss 1999).

On the other hand, while Austrian insights are useful for interpreting recent claims, these insights are also useful for understanding their reach. In particular, Misesian insights are helpful here, and it may be argued that their is a certain imbalance in the above writings because of their neglect of these insights. Thus, I have argued that Mises' insights in entrepreneurship, property rights and the complementarity of elements in economic systems are useful ones for claiming a role for authority and the boundaries of firms, as well as for helping to uphold the notion that there are discrete organizational forms (e.g., firms, markets, and hybrids), and that coordination mechanisms cannot be combined arbitrarily. This strongly suggests that Austrian economics (still) has an important contribution to make to the study of economic organization; in particular, that important principles of efficient organization design can be derived from Misesian foundations.

\section{References}

Aghion, Philippe and Jean Tirole. 1997. "Formal and Real Authority in Organization," Journal of Political Economy 105: 1-29. 
Alchian, Armen A. and Harold Demsetz. 1972. "Production, Information Costs, and Economic Organization," in Armen A. Alchian. 1977. Economic Forces at Work. Indianapolis: Libert Press.

Baker, George, Robert Gibbons, and Kevin J. Murphy. 1999. "Informal Authority in Organizations," Journal of Law, Economics and Organization 15: 56-73.

Boisot, Max. 1998. Knowledge Assets: Securing Competitive Advantage in the Information Economy. Oxford: Oxford University Press.

Bolton, Patrick and Joseph Farrell. 1990. "Decentralization, Duplication, and Delay," Journal of Political Economy 98: 803-826.

Boudreaux, Donald and Randall Holcombe 1989. “The Coasian and Knightian Theories of the Firm," Managerial and Decision Economics 10: 147-154.

Brynjolfsson, Erik. 1994. "Information Assets, Technology, and Organization," Management Science 40: 1645-1662.

Casson, Mark. 1994. "Why are Firms Hierarchical?," International Journal of the Economics of Business 1: 47-76.

Chandler, Alfred D. 1962. Strategy and Structure: Chapters in the History of the American Industrial Enterprise. Cambridge: MIT Press.

Cheung, Stephen N.S. 1983. "The Contractual Nature of the Firm," Journal of Law and Economics 26: 1-22.

Coase, Ronald H. 1937. "The Nature of the Firm," in Nicolai J. Foss, ed. 1999. The Theory of the Firm: Critical Perspectives in Business and Management, Vol II. London: Routledge.

Cowen, Tyler and David Parker. 1997. Markets in the Firm: A Market Process Approach to Management. London: The Institute of Economic Affairs.

D'Aveni, Richard. 1994. Hypercompetition: The Dynamics of Strategic Maneuvering. New York: Basic Books.

Demsetz, Harold. 1988. "The Theory of the Firm Revisited," Journal of Law, Economics, and Organization 4: 141-161.

Ellig, Jerry. 1993. "Internal Pricing for Corporate Services," Working Paper in MarketBased Management, Centre for the Study of Market Processes, George Mason University.

Ellig, Jerry. 1997. "From Austrian Economics to Market-Based Management," Journal of Private Enterprise 13: 133-146.

Ellig, Jerry and Wayne Gable. 1993. Introduction to Market-Based Mangement. Fairfax, VA: Center for Market Processes.

Fama, Eugene and Michael C. Jensen 1983. "Separation of Ownership and Control," Journal of Law and Economics 26: 301-325.

Foss, Kirsten. 2000. “Organizing Technological Interdependencies: A Coordination Perspective on the Firm", Industrial and Corporate Change 10: 151-178.

Foss, Nicolai J. 1993. "More on Knight and the Theory of the Firm". Managerial and Decision Economics 14: 269-276. 
Foss, Nicolai J. 1994a. "Ludwig von Mises: Precursor of Property Rights Economics," in idem., ed. 1994. The Austrian School and Modern Economics: Essays in Reassessment. Copenhagen: Munksgaard.

Foss, Nicolai J. 1994b. "The Theory of the Firm: The Austrians as Precursors and Critics of Contemporary Theory". Review of Austrian Economics 7 (1): 31-65.

Foss, Nicolai J. 1999. "The Use of Knowledge in Firms", Journal of Institutional and Theoretical Economics 155: 458-486.

Foss, Nicolai J. 2000. "The Costs of Internal Hybrids: The Rise and Decline of the Oticon Spaghetti Organization," LINK Working Paper 2000-18 (downloadable from http://www.cbs.dk/link/papers).

Ghoshal, Sumantra, Peter Moran and Luis Almeida-Costa. 1995. "The Essence of the Megacorporation: Shared Context, not Structural Hierarchy", Journal of Institutional and Theoretical Economics 151: 748-759.

Grandori, Anna. 1997. "Governance Structures, Coordination Mechanisms and Cognitive Models," Journal of Management and Governance 1: 29-42.

Grant, Robert M. 1996. "Prospering in Dynamically-Competitive Environments: Organizational Capability as Knowledge Integration," Organization Science 7: 375-387.

Hamel, Gary and C.K. Prahalad. 1994. Competing for the Future. New York: Free Press.

Harryson, Sigvald J. 2000. Managing Know-Who Based Companies. Cheltenham: Edward Elgar.

Hart, Oliver. 1995. Firms, Contracts, and Financial Structure. Oxford: Oxford University Press.

Hart, Oliver. 1996. "An Economist's View of Authority," Rationality and Society 8: 371-386.

Hart, Oliver and John Moore. 1990. "Property Rights and the Nature of the Firm," Journal of Political Economy 98: 1119-1158.

Hayek, Friedrich A. 1937. "Economics and Knowledge," in idem. 1948. Individualism and Economic Order. Chicago: University of Chicago Press.

Hayek, Friedrich A. 1945. "The Use of Knowledge in Society," in idem. 1948. Individualism and Economic Order. Chicago: University of Chicago Press.

Hayek, Friedrich A. 1946. "The Meaning of Competition," in idem. 1948. Individualism and Economic Order. Chicago: University of Chicago Press.

Hayek, Friecrich A. von. 1968. "Competition as a Discovery Proceure," in idem. 1978, New Studies in Philosophy, Economics, Politics, and the History of Ideas, London: Routledge and Kegan Paul.

Hayek, Friedrich A. von 1973. Law, Legislation, and Liberty, Vol.1: Rules and Order, Chicago: University of Chicago Press.

Helper, Susan, John Paul MacDuffie, and Charles Sabel. 2000. "Pragmatic Collaborations: Advancing Knowledge While Controlling Opportunism," Industrial and Corporate Change 9: 443-487. 
Hodgson, Geoff. 1998. Economics and Utopia. London: Routledge.

Holmström, Bengt. 1979. "Moral Hazard and Observability," Bell Journal of Economics 10: 74-91.

Holmström, Bengt and Paul Milgrom. 1991. "Multitask Principal-Agent Analysis: Incentive Contracts, Asset Ownership and Job Design," Journal of Law, Economics and Organization 7: 24-54.

Ichniowski, Casey, Thomas A. Kochan, David Levine, Craig Olson and George Strauss. 1996. "What Works at Work: Overview and Assessment," Industrial Relations 35: 299-333."

Jensen, Michael C. and William H. Meckling. 1992. "Specific and General Knowledge and Organizational Structure," in Lars Werin og Hans Wijkander, eds. 1992. Contract Economics. Oxford: Blackwell.

Jensen, Michael C. and Karen Wruck. 1994. "Science, Specific Knowledge and Total Quality Management," in Michael C. Jensen. 1998. Foundations of Organizational Strategy. Cambridge: Harvard University Press.

Kirzner, Israel M. 1997. "Entrepreneurial Discovery and the Competitive Market Process: An Austrian Approach," Journal of Economic Literature 35: 60-85.

Klein, Peter. 1996. "Economic Calculation and the Limits of Organization," Review of Austrian Economics 9: 3-28.

Klein, Peter and Sandra Klein. 2001. “Do Entrepreneurs Make Predictable Mistakes? Evidence from Corporate Divestitures," forthcoming, Quarterly Journal of Austrian Economics.

Knight, Frank H. 1921. Risk, Uncertainty, and Profit. 1965 reprint. New York: Augustus M. Kelley.

Langlois, Richard N. 1992. "Transaction-Cost Economics in Real Time," Industrial and Corporate Change 1: 99-127.

Langlois, Richard. 2001. "The Vanishing Hand: the Modular Revolution in American Business," unpublished paper.

Laursen, Keld and Nicolai J. Foss. 2002. "New HRM Practices, Complementarities, and the Impact on Innovation Performance," forthcoming in Cambridge Journal of Economics.

Liebeskind, Julia Porter, Amalya Lumerman Oliver, Lynne G. Zucker, Marilynn B. Brewer. 1995. Social Networks, Learning, and Flexibility: Sourcing Scientific Knowledge in New Biotechnology Firms. Cambridge: NBER Working Paper No. W5320.

Matthews, Don. 1998. "Management versus the Market: An Exaggerated Distinction," Quarterly Journal of Austrian Economics 1: 41-46.

Matusik, Sharon F. and Charles W. L. Hill. 1998. "The Utilization of Contingent Work, Knowledge Creation, and Competitive Advantage," Academy of Management Review 23: 680-697.

Mendelson, Haim and Ravindran R. Pillai. 1999. "Information Age Organizations, Dynamics, and Performance," Journal of Economic Behavior and Organization 38: 253-281. 
Miles, Raymond E. and Charles C. Snow. 1992. "Causes of Failure in Network Organizations," California Management Review: 53-72.

Miles, Raymond E., Charles C. Snow, John A. Mathews, Grant Miles and Henry J. Coleman, Jr. 1997. "Organizing in the Knowledge Age: Anticipating the Cellular Form," Academy of Management Executive 11: 7-20.

Milgrom, Paul. 1988. "Employment Contracts, Influence Activities and Efficient Organization Design," Journal of Political Economy 96:42-60.

Milgrom, Paul and John Roberts. 1990. “The Economics of Modern Manufacturing: Technology, Strategy and Organization," American Economic Review 80: 511528.

Miller, Gary. 1992. Managerial Dilemmas. Cambridge: Cambridge University Press.

Minkler, Alanson P. 1993. "Knowledge and Internal Organization," Journal of Economic Behavior and Organization 21: 17-30.

Mises, Ludwig von. 1936. Socialism. Indianapolis: Liberty Press.

Mises, Ludwig von. 1949. Human Action. San Francisco: Fox and Wilkes.

Myers, Paul S. 1996. Knowledge Management and Organizational Design. Boston: Butterworth-Heinemann.

Neef, Dale. 1998. The Knowledge Economy. Boston: Heinemann-Butterworth.

Nonaka, Ikujiro and Takeuchi. 1995. The Knowledge-Creating Company. Oxford: Oxford University Press.

Powell, Walter. 1990. "Neither Market, Nor Hierarchy: Network Forms of Organization," Research in Organizational Behavior 12: 295-336.

Prusak, Laurence. 1997. Knowledge in Organizations. Boston: ButterworthHeinemann.

Semler, Ricardo. 1989. “Managing Without Managers," Harvard Business Review (Sept.-Oct.): 76-84.

Tomlinson, Mark. 1999. “The Learning Economy and Embodied Knowledge Flows in Great Britain," Journal of Evolutionary Economics 9: 431-451.

Williamson, Oliver E. 1996. The Mechanisms of Governance. Oxford: Oxford University Press.

Zenger, Todd and William S. Hesterly. 1997. "The Disaggregation of Corporations: Selective Intervention, High-Powered Incentives, and Molecular Units," Organization Science 8: 209-222.

Zingales, Luigi. 2000. "In Search of New Foundations," forthcoming in Journal of Finance.

Zucker, Lynne. 1991. “Markets for Bureaucratic Authority and Control: Information Quality in Professions and Services," Research in the Sociology of Organizations 8: 157-190. 
